\title{
ЗАГАЛЬНА СЕРЕДНЯ ОСВІТА УКРАЇНИ В КОНТЕКСТІ ОСВІТИ КРӒ̈Н ЄВРОПИ: ТРИВАЛІСТЬ І СТРУКТУРА
}

\author{
Науково-аналітична доповідь
}

https://doi.org/10.37472/2707-305X-2020-2-2-14-1

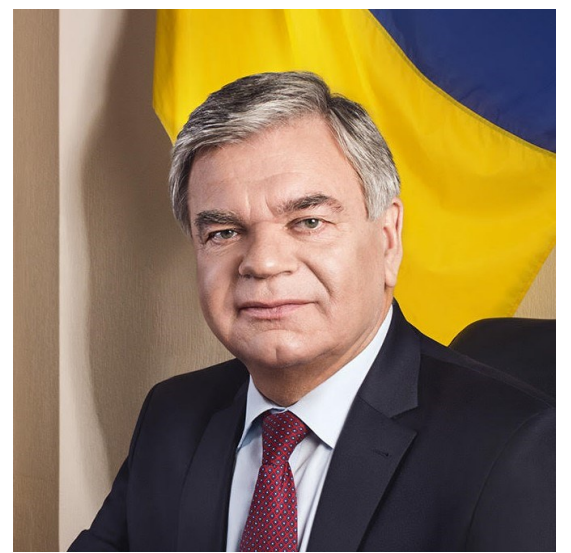

KPEMEHЬ

\section{Василь Григорович}

доктор фрілософрських наук, профессор, дійсний член (академік) НАН України і НАПН України, президент Національної академії педагогічних наук України, м. Київ, Україна

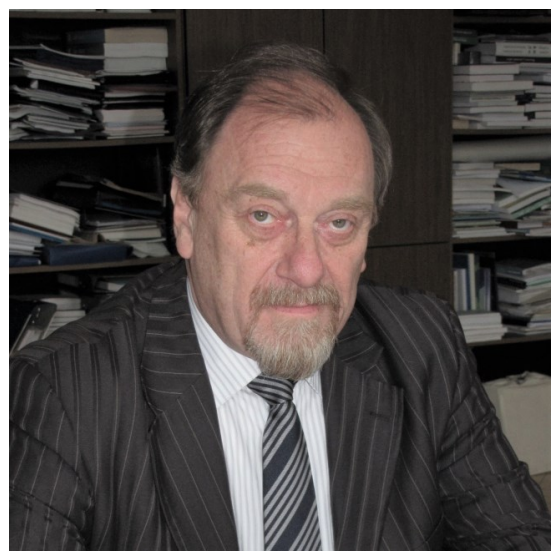

\section{ЛЯШЕНКО}

\section{Олександр Іванович}

доктор педагогічних наук, професор, дійсний член (академік) НАПН України, академік-секретар Відділення загальної середньої освіти Національної академії педагогічних наук України, м. Київ, Україна

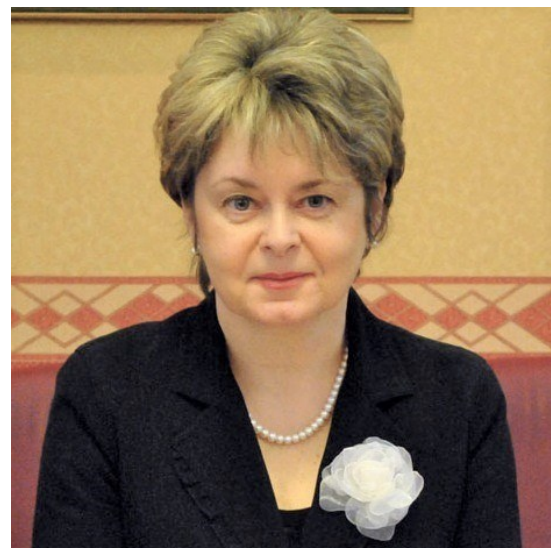

ЛОКШИНА

\section{Олена Ігорівна}

доктор педагогічних наук, профресор, член-кореспондент НАПН України, завідувачка відділу порівняльної педагогіки Iнституту педагогіки Національної академіі педагогічних наук України, м. Київ, Україна

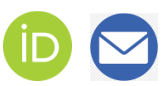

Анотація. У науково-аналітичній доповіді здійснено порівняльний аналіз структури національної системи загальної середньої освіти України та освітніх систем 38 країн, що входять до програми Європейського Союзу Erasmus+ (27 країн-членів ЄC, а також Албанія, Боснія та Герцеговина, Сполучене Королівство Великої Британії та Північної Ірландії, Ісландія, Ліхтенштейн, Норвегія, Північна Македонія, Сербія, Туреччина, Чорногорія, Швейцарія). Проаналізовано тривалість навчання і структуру навчального року в Україні та країнах Європи, зроблено висновки щодо відповідності навчального часу і канікул у вітчизняних і європейських закладах загальної середньої освіти. На основі основних тенденцій розвитку освіти в Європейському освітньому просторі сформульовано пропозиціі щодо удосконалення організації освітнього процесу в українських школах у контексті трансформаційних процесів, що нині відбуваються у загальній середній освіті України.

Ключові слова: повна загальна середня освіта; освітні системи країн Європи; система загальної середньої освіти України; тривалість навчання; структура навчального року; реформування загальної середньої освіти України.

\section{І. Вступ}

Україна як європейська держава поділяє спільну історію і спільні цінності $з$ країнамичленами Європейського Союзу (далі - ЄС), що відкриває їй нові можливості в своїй європейській ідентичності. Європейський вибір України підтверджує Угода про асоціацію між Україною та Європейським Союзом (2014), а також численні 
угоди, заяви і політичні кроки, які характеризують вектор розвитку нашої держави.

Важливою складовою інтеграції України є входження національної системи освіти до Європейського освітнього простору. Актуальним у цьому сенсі $€$ порівняльний аналіз розвитку національної системи загальної середньої освіти України в контексті змін в освіті країн Європи, зокрема членів ЄC, осмислення сутності реформ та інновацій, які упроваджуються нині в Європейському освітньому просторі.

У цьому огляді структура повної загальної середньої освіти розглядається відповідно до Міжнародної стандартної класифікації освіти (МСКО) ЮНЕСКО (2011), яка охоплює три рівні: МСКО 1 початкова освіта, МСКО 2 - базова середня освіта, МСКО 3 - профільна середня освіта. За необхідності вживається також МСКОО - дошкільна освіта, МСКО 4 - післясередня невища освіта (UNESCO Institute for Statistics, 2012).

Аналізом охоплено національну систему загальної середньої освіти України та освітні системи 38 країн, що входять до програми Європейського Союзу Erasmus+ (27 країн-членів ЄC, Албанія, Боснія та Герцеговина, Сполучене Королівство Великої Британії та Північної Ірландії (далі - Сполучене Королівство), Ісландія, Ліхтенштейн, Норвегія, Північна Македонія, Сербія, Туреччина, Чорногорія, Швейцарія).

II. Орієнтири ЄC, які окреслюють розвиток загальної середньої освіти

В умовах розбудови суспільства знань ЄС реалізує Стратегію «Європа 2020» (2010), що проголошує пріоритет розумного, стійкого та всеосяжного зростання з метою підвищення конкурентоспроможності й продуктивності країн Європи та підтримки стійкої соціальної ринкової економіки (European Commission, 2010).

Освіта розглядається як ефективний інструмент розвитку знаннєвої економіки та соціальної злагоди. Стратегічна програма європейського співробітництва в освіті «Освіта і навчання 2020» спрямовує держави-члени ЄС на створення національних систем освіти високої якості для усіх верств населення упродовж життя. Програма окреслює такі стратегічні цілі:

- перетворити освіту упродовж житта та мобільність на реальність;

- підвищити якість та продуктивність освіти і навчання;

- сприяти рівності можливостей, соціальній згуртованості й активному громадянству;
- підвищити творчість та інновації, включаючи підприємливість, на всіх рівнях освіти $i$ навчання.

Програма визначає такі орієнтири для досягнення цілей національними системами освіти до 2020 р.:

- щонайменше 95\% dimeй повинні бути охоплені ранньою і дошкільною освітою;

- має бути менше 15\% 15-річних, які демонструють низькі результати з читання, математики та природознавства (Science);

- відсоток молоді, яка зарано кидає навчання у віці 18-24 років, повинен бути нижче 10\%;

- принаймні 40\% населення у віці 30-34 років повинно мати закінчену вищу освіту;

- принаймні 15\% дорослого населення повинно навчатися;

- щонайменше 20\% випускників вищої освіти ma 6\% 18-34-річних з початковою професійною кваліфікацією мають навчатись певний час за кордоном;

- частка випускників закладів освіти у віці 2034 років зі здобуттям принаймні середньої освіти повинна становити не менше $82 \%$ (Council of the European Union, 2009).

У травні 2015 р. в Інчхоні (Республіка Корея) Всесвітній освітній форум представників 160 держав прийняв Декларацію «Освіта 2030. На шляху до всеохоплюючої та справедливої якісної освіти та навчання упродовж життя для всіx» («Education 2030. Towards inclusive and equitable quality education and lifelong learning for all») (UNESCO et al., 2015), якою позначив подальші кроки розбудови світового освітнього простору розвитку національних освітніх систем відповідно до Цілі Сталого Розвитку 4 «Забезпечення всеосяжної та справедливої якості освіти та сприяння можливостям навчання впродовж усього життя».

Як підкреслюється у повідомленні Комісії Європейському Парламенту «Розвиток школи та відмінне викладання для успішного початку життя» (European Commission, 2017), «якісна освіта для всіх сприятиме досягненню ЄС запланованих економічних та соціальних цілей. Якісна освіта лежить в основі інклюзивних та стійких суспільств. Це початок успішної професійної кар'єри та найкращий захист від безробіття й бідності. Освіта сприяє особистому розвитку та закладає основу для активного громадянства. Якісна освіта сприяє дослідницькій діяльності, інноваціям та конкурентоспроможності». 
Пріоритетами політики на рівні середньої освіти країн ЄС визначено:

- Усі учні повинні набути ключових компетентностей для навчання упродовж життя. Це може забезпечуватися шляхом переструктурування освітніх програм і методів оцінювання, перепідготовкою учителів, поліпшення навчальних засобів і ресурсів.

- Кожен учень має отримати користь від ранньої та дошкільної освіти, яка повинна стати більш доступною.

- Потрібно поліпшити підтримку учнів зі спеціальними потребами, включно з мігрантами та зменшити відсоток молоді, яка зарано залишає навчання у школі.

- Необхідно забезпечити вищий рівень підтримки (професійного розвитку, спростити мобільність) шкільним учителям, керівникам шкіл і викладачам, які готують учителів.

- Потрібно продовжувати розбудовувати систему забезпечення якості для створення більш ефективного й результативного управління шкільною освітою (European Commission - Education and Training, n.d.).

Принагідно зазначимо, що Інчхонською Декларацією «Освіта 2030» серед іншого визначено таке: «... ми забезпечимо надання 12 років безкошмовної, фрінансованої державою, справедливої і якісної початкової та середньої освіти, з яких принаймні дев'ять років є обов'язковими, що приведе до відповідних результатів навчання. Ми також заохочуємо надання щонайменше одного року безкоштовної та обов'язкової якісної дошкільної освіти, щоб усі діти мали доступ до якісного раннього дитинства, догляду та освіти. Ми також зобов'язуємося завдяки своїм цілеспрямованим і послідовним діям надавати можливості для освіти та профресійного навчання значній кількості дітей і підлітків, які не відвідують школу, щоб усі діми були в школі та навчалися» (UNESCO et al., 2015).

III. Тривалість і структура повної загальної середньої освіти в Україні та країнах Європи

Тривалість шкільної освіти безпосередньо пов' язується із економічним і соціальним розвитком країни. Так, ії вплив на суспільство загалом і кожного громадянина зокрема розглядається у двох аспектах - під кутом зору так званого монетарного (ринкового) та соціального впливів. Монетарний вплив охоплює окремих індивідуумів та економіки країн загалом. На прикладі європейських країн дослідники встановили, що кожен додатко- вий рік навчання асоціюється з більш ніж 8\% збільшення рівня заробітної платні у вже дорослого населення (позитивний вплив на окремого індивідуума). Щодо позитивного монетарного впливу на економіку країни, то підраховано, що кожен додатковий рік навчання піднімає макроекономічну продуктивність безпосередньо на 6,2\% у країнах ЄC та на додаткові 3,1\% у перспективі завдяки внеску у прискорення технологічного прогресу. Позиція ЄС щодо стратегічної важливості освіти у XXI ст. формує загальну тенденцію подальшого подовження тривалості навчання у школі країн Європи як у межах обов'язкової, так і повної загальної середньої освіти.

В Україні згідно з Конституцією України та чинним освітнім законодавством повна загальна середня освіта є обов'язковою (Конституція України, 1996, стаття 53; Закон України «Про освіту», 2017, стаття 12; Закон України «Про повну загальну середню освіту», 2020, стаття 2). Навчан ня у початковій школі (рівень МСКО 1) починається у віці дитини 6 (7) років. За законами України «Про освіту» (2017р.), «Про повну загальну середню освіту» (2020р.) тривалість повної загальної середньої освіти становить 12 років, випускний вік учнів - 18 років. Але сьогодні і до 2030 р. ї тривалість фрактично становить 11 років (випускний вік учнів - 17 років), оскільки перехід на 12-річну загальну середню освіту відбувається поетапно:

- для початкової освіти (чотири роки навчання) перехід розпочався 1 вересня 2018 р.;

- для базової середньої освіти (п'ять років навчання) розпочнеться 1 вересня 2022 р.;

- для профільної середньої освіти (три роки навчання) розпочнеться 1 вересня 2027 р. (Закон України «Про повну загальну середню освіту», 2020, Прикінцеві та перехідні положення).

Водночас у чинному освітньому законодавстві визначено як обов'язкову також дошкільну освіту дітей п'ятирічного віку (Закон України «Про освіту», 2017, стаття 11; Закон України «Про дошкільну освіту», 2001, стаття 3), що не підкріплено відповідним формулюванням у Конституції України, яка обов'язковою освітою визначає лише повну загальну середню освіту.

Структура повної загальної середньої освіти в освітніх системах європейських країн доволі строката і залежить від традицій та освітньої політики, зокрема, у питанні обов'язковості ії здобуття. у більшості країн Європи початкова освіта mриває 4 або 6 років (10 і 17 країн відповідно); у 
7 країнах вона триває 5 років, у 6 країнах 7 або 8 років. Базова середня освіта в основному триває 3 або 4 роки (23 і 12 країн, відповідно), у 4 країнах - 5 або 6 років. Профрільну середню освіту здобувають за 3 роки в 17 країнах, за 4 роки - у 19 країнах, в одній країні (литва) вона дворічна (за тривалості базової середньої освіти 6 років), у $з$ країнах - п'ятирічна.

В Україні, як відомо, структура повної загальної середньої освіти в 11-річній школі нині така: початкова освіта (1-4 класи) - 4 роки, базова середня освіта (5-9 класи) - 5 років, профільна середня освіта (10-11 класи) - 2 роки; з 2027 р. профільна середня освіта подовжується на 1 рік і стає трирічною із упровадженням академічного й професійного спрямування.

Загальна середня освіта у країнах, що входили до складу СРСР у європейській його частині, після здобуття ними незалежності розвивалася за різними сценаріями залежно від політичної ситуації, культурних традицій і спрямувань освітньої політики.

Країни Балтійського регіону (Естонія, Латвія, Литва), які вступили до ЄС, трансформували свої національні системи загальної середньої освіти відповідно до вимог Європейського освітнього простору, змінивши структуру і подовживши термін здобуття повної загальної середньої освіти до 12 років. Наразі в Естонії ця освіта двоступенева. Базова освіта (1-9 класи) включає початкову (МСКО 1) і базову середню освіту (МСКО 2). Повна середня освіта (10-12 класи) має академічне (MCKO 3) і професійне спрямування (МСКО 3 і 4), здобувається у закладах і професійної (професійно-технічної), і фахової передвищої освіти. У Латвії повна загальна середня освіта має «класичне» для ЄС структурування: початкова освіта (1-6 класи), базова середня (7-9 класи), профільна середня освіта (10-12 класи). У Литві повна загальна середня освіта також триває 12 років, але має своєрідну структуру: початкова освіта (1-4 класи), базова середня (5-10 класи), профільна середня освіта (11-12 класи). В усіх трьох цих державах здобувачі повної загальноі середньої освіти завериують навчання у 19 років.

Після набуття статусу незалежних держав національні системи загальної середньої освіти Вірменії, Грузії та Молдови також запровадили 12річний термін здобуття повної загальної середньої освіти. У Вірменії і Молдові структура загальної середньої освіти майже не змінилася, лише подовжилася на один рік профільна освіта (старша школа): початкова освіта -4 роки, базова середня освіта - 5 років, профільна середня освіта - 3 роки. У Грузії національна система загальної середньої освіти дещо інша: початкова освіта - 6 років, базова середня - 3 роки, профільна середня - 3 роки.

На європейській частині пострадянського освітнього простору залишилися лише три держави, крім України, повна загальна середня освіта в яких триває 11 років. Це Азербайджан, Білорусь $i$ Росія. Жодна з них не декларує намірів інтеграції до загальноєвропейського освітнього простору, обмежуючись освітнім простором країн СНД.

В освітніх системах європейських країн тривалість повної загальної середньої освіти, що дає право вступу до університетів, становить не менше 12 років, зокрема в 19 країнах вона становить 12 років; у 17 країнах - 13 років; у 2 країнах - 14 років. В усіх країнах вік завершення їі здобувачами освіти становить 18 і більше років (табл. 1) (EACEA, 2019а).

Таблиия 1

Тривалість повної загальної середньої освіти в Україні та країнах Європи

\begin{tabular}{|l|l|}
\hline \multicolumn{1}{|c|}{ Країна } & \multicolumn{1}{|c|}{ Тривалість / вік учнів } \\
\hline Україна & $11(6-17)$ \\
\hline Австрія & $12(6-18)$ \\
\hline Албанія & $12(6-18)$ \\
\hline Бельгія & $12(6-18)$ \\
\hline Болгарія & $12(7-19)$ \\
\hline Боснія і Герцеговина & $13(6-19)$ \\
\hline Греція & $12(6-18)$ \\
\hline Данія & $13(6-19)$ \\
\hline Естонія & $12(7-19)$ \\
\hline Ірландія & $15(4-19)$ \\
\hline Ісландія & $13(6-19)$ \\
\hline Іспанія & $12(6-18)$ \\
\hline Італія & $13(6-19)$ \\
\hline Кіпр & $12,5 / 13,5(5,5-18 / 19)$ \\
\hline Латвія & $12(7-19)$ \\
\hline Литва & $12(7-19)$ \\
\hline Ліхтенштейн & $14(6-20)$ \\
\hline Люксембург & $13(6-19)$ \\
\hline Мальта & $13(5-18)$ \\
\hline Нідерланди & $12(6-18)$ \\
\hline Німеччина & $12 / 13(6-18 / 19)$ \\
\hline Норвегія & $13(6-19)$ \\
\hline Північна Македонія & $13,5(6-19,5)$ \\
\hline Польща & $12(7-19)$ \\
\hline Португалія & $12(6-18)$ \\
\hline Румунія & $13(6-19)$ \\
\hline
\end{tabular}


Таблиия 1 (продовження)

\begin{tabular}{|l|l|}
\hline \multicolumn{1}{|c|}{ Країна } & \multicolumn{1}{|c|}{ Тривалість / вік учнів } \\
\hline Сербія & $12(6,5-18,5)$ \\
\hline Словаччина & $13(6-19)$ \\
\hline Словенія & $13 / 14(6-19 / 20)$ \\
\hline $\begin{array}{l}\text { Сполучене Королівство Великої } \\
\text { Британії та Північної Ірландії: }\end{array}$ & \\
\hline \multicolumn{1}{|c|}{ Англія, Уельс, Шотландія } & $13(5-18)$ \\
\hline \multicolumn{1}{|c|}{ Північна Ірландія } & $14(4-18)$ \\
\hline Туреччина & $12(5,5-17,5)$ \\
\hline Угорщина & $13(6-19)$ \\
\hline Фінляндія & $12(7-19)$ \\
\hline Франція & $12(6-18)$ \\
\hline Хорватія & $12(7-19)$ \\
\hline Чехія & $13(6-19)$ \\
\hline Чорногорія & $13(6-19)$ \\
\hline Швейцарія & $13(6-19)$ \\
\hline Швеція & $12(7-19)$ \\
\hline
\end{tabular}

Варто зазначити, що в більшості країн Європи, на відміну від України, повна загальна середня освіта не $\epsilon$ законодавчо обов'язковою. Обов'язкова освіта охоплює в них як мінімум початкову та базову середню (МСКО 1 та 2) і в більшості країн продовжується ще 1-2 роки в старшій школі; у 4 країнах (і їх кількість із кожним роком зростає) до обов'язкової належить також профільна середня освіта в старшій школі в різних їі формах (МСКО 3), тобто повна загальна середня освіта $\epsilon$ обов'язковою.

Загалом у країнах Європи понад 95\% здобувачів обов'язкової базової середньої освіти продовжують навчання за академічними чи професійними освітніми програмами в старшій школі попри ї̈ необов'язковість. У 16 країнах Європи обов'язковою також $є$ дошкільна освіта (МСКО 0) різної тривалості (табл. 2).

Нині в країнах Європи близько 50\% здобувачів повної загальної середньої освіти опановують загальноосвітні академічні програми, решта здобувають освіту за програмами набуття професії. Частка здобувачів освіти, які навчаються за загальноосвітніми/академічними програмами, у більшості країн становить 30-70\%; найнижчий цей показник у Чехії, Фінляндії та Словенії (25-30\%), найвищий - в Угорщині (77\%) та Ірландії (89\%).

В Україні більшість учнів $(64,8 \%)$ після здобуття базової середньої освіти (9 класів) продовжують навчання у старшій школі (10-11 класи), закладах професійної (професійно-технічної) освіти (14,7\%) або професійних коледжах і технікумах (19,6\%) (Державна служба статистики України, 2020). У 2019 р. лише один відсоток випускників 9 класу не продовжив навчання. Водночас викликає занепокоєння стійка тенденція щорічного зниження кількості випускників 9 класу, які йдуть здобувати професію: за останні чотири роки частка таких учнів впала від 38,7\% до 34,3\%, тобто на 4,4\%.

Висновки. Порівняльний аналіз наведених показників освіти засвідчує, що тривалість здобуття повної загальної середньої освіти в Україні нині є найменшою в Європі і лише запровадження 12-річної загальної середньої освіти фактично дасть змогу досягнути найнижчого показника європейських країн. За збереження нинішньої 11-річної школи випускники українських шкіл не зможуть конкурувати з ровесниками із європейських країн, а українська освіта - органічно ввійти в європейський і світовий освітні простори. Показовим є приклад Туреччини, яка при анонсуванні наміру вступу до ЄС змушена змінити своє освітнє законодавство та збільшити тривалість здобуття повної загальної середньої освіти до 12 років.

Водночас слід зазначити, що згідно з Конституцією України повна загальна середня освіта $\epsilon$ обов'язковою, що відповідає кращим європейським зразкам, але створює для держави певні труднощі як у фінансовому, так і соціальному вимірі.

На нашу думку, цю конституційну норму обов'язковості освіти було б доцільно трактувати так: держава створює можливості для здобуття повної загальної середньої освіти впродовж життя, але не вимагає обов'язкового ії набуття до 18 років. Адже частина випускників 9 класу має наміри здобути професію, а не загальну середню освіту, і піти працювати. Такий підхід розвантажить профільну старшу школу від учнів, які на цьому етапі не спроможні чи не планують опанувати відповідну освітню програму, і скоротить бюджетні витрати на профільну середню освіту. Водночас ці випускники 9 класу можуть здобути професію у закладах професійної (професійно-технічної) освіти за освітніми програмами професійного спрямування без набуття повної загальної середньої освіти та поповнити ряди працюючих у різних сферах економіки.

Крім того, на нашу думку, слід ліквідувати дисбаланс мін тими, хто здобуває вищу освіту, i тими, хто здобуває фрах на відповідних (четвертому і п'ятому) рівнях освіти і йде працювати. Для цього варто сприяти зростанню частки випускників 9 класів, які здобуватимуть професійну (професійно-технічну) і фахову передвищу освіту на основі базової середньої освіти після 
Табличя 2

Тривалість обов'язкової освіти в Україні та країнах Європи

\begin{tabular}{|c|c|c|c|c|c|c|c|c|c|c|c|c|c|}
\hline & \multicolumn{12}{|c|}{ Обов'язкова освіта } \\
\hline & & \multicolumn{5}{|c|}{ Вік початку } & \multicolumn{6}{|c|}{ Вік закінчення } & \multirow{2}{*}{$\begin{array}{c}\text { Тривалість } \\
\text { (у роках) }\end{array}$} \\
\hline & & 3 & 4 & 5 & 6 & 7 & 14 & 15 & 16 & 17 & 18 & 19 & \\
\hline \multicolumn{2}{|c|}{ Україна (станом на 2020 р.) } & & & & 6 & & & & & 17 & & & 11 \\
\hline \multicolumn{2}{|c|}{ Україна з 2030 р. } & & & & 6 & & & & & & 18 & & 12 \\
\hline \multicolumn{2}{|c|}{ Австрія } & & & 5 & & & & 15 & & & & & 10 \\
\hline \multicolumn{2}{|l|}{ Албанія } & & & & 6 & & & 15 & & & & & 9 \\
\hline \multicolumn{2}{|l|}{ Бельгія } & & & & 6 & & & & & & 18 & & 12 \\
\hline \multicolumn{2}{|l|}{ Болгарія } & & & 5 & & & & & 16 & & & & 11 \\
\hline \multicolumn{2}{|c|}{ Боснія і Герцеговина } & & & & 6 & & & 15 & & & & & 9 \\
\hline \multicolumn{2}{|c|}{ Греція } & & 4 & & & & & 15 & & & & & 11 \\
\hline \multicolumn{2}{|l|}{ Данія } & & & & 6 & & & & 16 & & & & 10 \\
\hline \multicolumn{2}{|l|}{ Естонія } & & & & & 7 & & & 16 & & & & 9 \\
\hline \multicolumn{2}{|l|}{ Ірландія } & & & & 6 & & & & 16 & & & & 10 \\
\hline \multicolumn{2}{|l|}{ Ісландія } & & & & 6 & & & & 16 & & & & 10 \\
\hline \multicolumn{2}{|l|}{ Іспанія } & & & & 6 & & & & 16 & & & & 10 \\
\hline Італія & & & & & 6 & & & & 16 & & & & 10 \\
\hline Кіпр & & & $4 p .8 \mathrm{~m}$. & & & & & 15 & & & & & 10 \\
\hline Латвія & & & & 5 & & & & & 16 & & & & 11 \\
\hline Литва & & & & & 6 & & & & 16 & & & & 10 \\
\hline Ліхтенштеі & & & & & 6 & & & 15 & & & & & 9 \\
\hline Люксембу & & & 4 & & & & & & 16 & & & & 12 \\
\hline Македонія & & & & 5 p.7м. & & & & & & 17 & & 19p.6м. & $11-13$ \\
\hline Мальта & & & & 5 & & & & & 16 & & & & 11 \\
\hline Нідерланд & & & & 5 & & & & & 16 & & & & 11 \\
\hline Німеччина & (5 земель) & & & & 6 & & & & & & & 19 & 13 \\
\hline Німеччина & (11 земель) & & & & 6 & & & & & & 18 & & 12 \\
\hline Норвегія & & & & & 6 & & & & 16 & & & & 10 \\
\hline Польща & & & & & 6 & & & 15 & & & & & 9 \\
\hline Португалія & & & & & 6 & & & & & & 18 & & 12 \\
\hline Румунія & & & & & 6 & & & & & 17 & & & 11 \\
\hline Сербія & & & & 5 p.6м. & & & 14p.6м. & & & & & & 9 \\
\hline Словаччин & & & & & 6 & & & & 16 & & & & 10 \\
\hline Словенія & & & & & 6 & & & 15 & & & & & 9 \\
\hline $\begin{array}{l}\text { Сполучене } \\
\text { Великої Бр } \\
\text { Північної І }\end{array}$ & $\begin{array}{l}\text { Королівство } \\
\text { итанії та } \\
\text { лландії: }\end{array}$ & & & & & & & & & & & & \\
\hline Англія & & & & 5 & & & & & 16 & & & & 11 \\
\hline Уельс & & & & 5 & & & & & 16 & & & & 11 \\
\hline Північн & а Ірландія & & 4 & & & & & & 16 & & & & 12 \\
\hline Шотлаң & дія & & & 5 & & & & & 16 & & & & 11 \\
\hline Туреччина & & & & 5 p.9м. & & & & & & 17p.6м. & & & 12 \\
\hline Угорщина & & 3 & & & & & & & 16 & & & & 13 \\
\hline Фінляндія & & & & & 6 & & & & 16 & & & & 10 \\
\hline Франція & & 3 & & & & & & & 16 & & & & 13 \\
\hline Хорватія & & & & & & 7 & & 15 & & & & & 8 \\
\hline Чехія & & & & 5 & & & & 15 & & & & & 10 \\
\hline Чорногорія & & & & & 6 & & & 15 & & & & & 9 \\
\hline Швеція & & & & & 6 & & & & 16 & & & & 10 \\
\hline Швейцарія & & & 4 & & & & & 15 & & & & & 11 \\
\hline Вік початку & - MCKO 0 & 1очатку & $-M$ & ICKO 1 & & & & & & & & & \\
\hline
\end{tabular}


9 класу в професійних ліцеях, коледжах, технікумах та інших закладах освіти.

IV. Структура навчального року в Україні та країнах Європи

Незважаючи на певні відмінності в організації освітнього процесу, країни Європи демонструють багато спільних рис щодо структури навчального року (ЕACEA, 2019b).

У більшості європейських країн навчальний рік починається на початку вересня; у 18 європейських країнах (регіонах) навчальний рік починається, як і в Україні, 1 вересня. У 10 країнах (як правило, північної Європи) він починається у серпні: раніше за всіх - у Данії і Фінляндії. у Німеччині школи в різних землях фактично починають навчання між 5 серпня і 11 вересня, хоча офіційна дата початку навчального року -1 серпня. У деяких країнах (як правило, південної Європи) дата початку навчання зазвичай припадає на середину вересня (Албанія, Греція, Італія, Португалія, Іспанія); на Мальті діти йдуть до школи наприкінці вересня. В Австрії, Німеччині, Іспанії, Італії, Нідерландах та Швейцарії початок і кінець навчального року значною мірою залежить від регіонів.

у початковій школі країн Європи діапазон значень рекомендованого річного мінімального навчального часу за умовний навчальний рік перебуває у межах від 469 стандартних (астрономічних) годин на рік у Болгарії до 1051 годин у Данії*. у чотирьох країнах (Данія, Ірландія, Люксембург, Нідерланди) рекомендований мінімальний навчальний час за умовний навчальний рік перевищує 900 стандартних (астрономічних) годин, у семи країнах (Болгарія, Боснія і Герцеговина, Латвія, Литва, Румунія, Хорватія, Чорногорія) він менше 600 годин. У початковій освіті європейських країн рекомендований мінімальний навчальний час (тобто нижня межа) за умовний навчальний рік у середньому дорівнюе 740 стандартних (астрономічних) годин.

В Україні гранично допустиме річне навчальне навантаження на учня початкової школи (тобто верхня межа) становить лише 499 стандартних (астрономічних) годин на рік (діагр. 1). Тобто впродовж навчального року українські школярі навчаються в початковій школі у півтора рази менше, ніж їхні однолітки з Європи, хоча опано-

*Порівнювалися різні часові параметри організації навчального процесу в різних країнах світу, наприклад, тривалість уроку (вона може бути від 35 до 50 хвилин), кількість днів у навчальному році, кількість років навчання на відповідному рівні освіти тощо. Для цього зроблено перерахунок навчального часу в стандартні (астрономічні) години тривалістю 60 хвилин, а також застосований так званий умовний навчальний рік, тривалість якого нівелюється щодо відмінностей кожної країни з кількості навчальних днів.

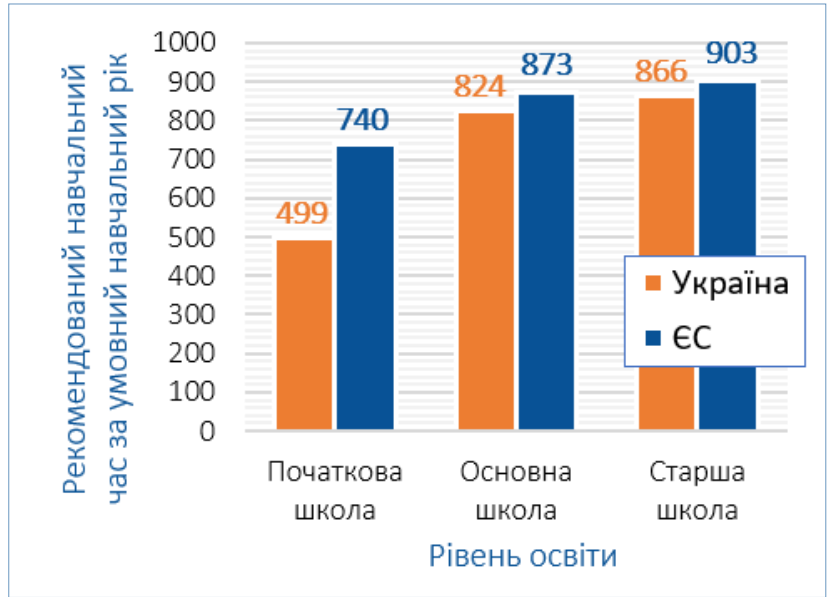

Діаграма 1. Гранично допустиме навчальне навантаження на рік здобувачів базової середньої освіти України і рекомендований мінімум навчального часу на рік країн Європи

вують не менший, навіть інколи більший обсяг навчального матеріалу. Звідси виникає проблема перевантаження учнів початкової школи, яка останнім часом усе більше турбує педагогічну громадськість і батьків, адже інтенсивність навчальної діяльності дітей, які лише починають адаптуватися до умов шкільного навчання, зависока.

У країнах Європи діапазон значень рекомендованого річного мінімального навчального часу за умовний навчальний рік для базової середньої освіmи (MCKO 2) лежить у межах від 637 стандартних (астрономічних) годин на рік у Хорватії до 1200 стандартних (астрономічних) годин на рік у Данії. В Іспанії, Нідерландах, Сполученому Королівстві (освітня система Північної Ірландії) він також перевищує 1000 стандартних (астрономічних) годин на рік. Загалом у європейських країнах рекомендований мінімальний навчальний час за умовний навчальний рік на рівні базової середньої освіти перевищує показник рівня початкової освіти в середньому на 133 стандартні (астрономічні) години і становить 873 години.

В українських школах на рівні базової середньої освіти (5-9 класи) відповідно до чинного державного стандарту гранично допустиме навчальне навантаження на учнів становить 824 стандартні (астрономічні) години за умовний навчальний рік, тобто на 49 годин менше за середнє значення (873 години) рекомендованого мінімального навчального часу за умовний навчальний рік у країнах ЄC.

у профільній старшій школі європейських країн для академічних (загальноосвітніх) програм, що надають доступ до наступного рівня вищої освіти, середнє значення рекомендованого мінімуму навчального часу за умовний рік сягає 
903 стандартні (астрономічні) години, що на 30 годин більше, ніж на рівні базової середньої освіти**. В Іспанії, Франції, Сполученому Королівстві (освітня система Північної Ірландії) рекомендований мінімум навчального часу становить близько 1000 стандартних (астрономічних) годин і більше; у Північній Македонії він найменший 774 години. В окремих країнах, наприклад, у Сполученому Королівстві (освітні системи Англії і Шотландії) на цьому рівні не існує централізованих нормативних показників рекомендованого мінімуму навчального часу.

В Україні цей показник для старшої школи дорівнює 866 стандартних (астрономічних) годин на навчальний рік, тобто він менше середнього показника європейських країн на 37 годин і значно поступається системам освіти провідних європейських країн.

У країнах Євponи найбільш поширений діапазон кількості навчальних днів у навчальному році перебуває у межах від 170 до 190 днів. Приблизно в половині освітніх систем тривалість навчального року - в межах 180 днів; у 17 країнах) регіонах кількість навчальних днів коливається від 181 до 190 днів. Найкоротший навчальний рік у початковій школі Бельгії (фламандська спільнота) - 157,5 днів, найдовше діти навчаються у школах Данії та Італії (до 200 днів). У більшості країн кількість робочих днів у навчальному році в початковій та базовій середній освіті однакова. У середньому в країнах Європи навчальний рік у початковій школі триває 182 навчальні дні, в основній школі - 179 навчальних днів. У старшій школі діапазон навчальних днів у навчальному році ширший, оскільки залежить від типу освітньої програми, яку опановують здобувачі освіти, екзаменаційного періоду та інших чинників, що впливають на його тривалість. Цей показник ще вищий у країнах ОЕСР (діагр. 2).

В Україні навчальний рік триває 175 навчальних днів, тобто він ближче до нижньої межі тривалості навчального року в країнах ЄС. Насправді, враховуючи святкові дні, карантинні заходи (ще до пандемії COVID-19) та інші обставини, що виникають упродовж навчального року, фактично його тривалість ще менша; реальний навчальний рік, як правило, триває менше 170 навчальних (робочих) днів, оскільки традиційно завершується до 1 червня, незалежно від кількості відпрацьованих днів, хоча за законом навчальний рік може закінчуватися до 1 липня. Варто відзначити, що

** Дані наведено за 22 освітніми системами країн Європи, в яких на МСКО 3 хоча б один рік загальноосвітньої підготовки $€$ обов'язковим.

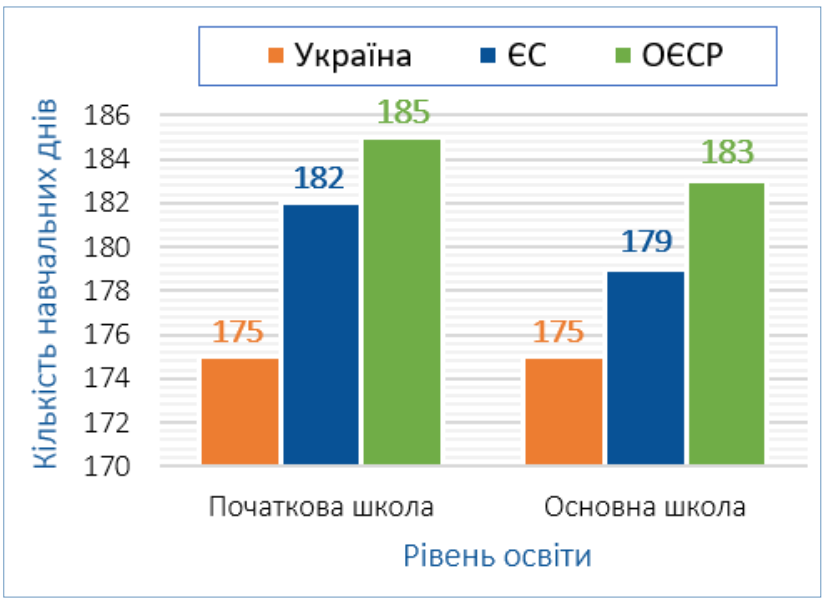

Діаграма 2. Тривалість навчального року в Україні, країнах ЄС та ОЕСР

за кількістю навчальних днів упродовж здобуття повної загальної середньої освіти нинішні українські школярі поступаються навіть здобувачам середньої освіти, які навчалися у радянський період у 10-річній школі, оскільки тоді був шестиденний робочий тиждень. Адже кожного навчального року нинішня 11-річна школа має на 35 навчальних днів меншу тривалість навчального року порівняно з 10-річною радянською школою. За 10 років навчання набігає 350 днів, що еквівалентно двом навчальним рокам по 175 днів. Тобто запровадження 12-річного терміну здобуття повної загальної середньої освіти чинним Законом України «Про освіту» практично поновлює кількість навчальних днів радянської «десятирічки».

у Європі навчальний рік, як правило, закінчується у середині червня, у цей час у більшості країн розпочинаються літні канікули. У європейських країнах час і тривалість канікул упродовж навчального року є різною. Окрім літніх канікул, у закладах середньої освіти країн Європи є ще чотири канікулярні періоди: осінні свята, різдвяні та новорічні, зимові карнавальні свята, а також весняні на Великдень. Початок літніх канікул залежить від структури навчального року конкретної країни і триває від 6 тижнів у Нідерландах, окремих землях Німеччини, Сполученому Королівстві до 13 тижнів у Албанії, Італії та Португалії.

В Україні літні канікули в початковій школі тривають 13 тижнів, в основній школі - 11-13 тижнів залежно від року навчання, що ближче до максимальних показників тривалості літніх канікул в країнах Європи.

Висновок. В Україні здобуття повної загальної середньої освіти на всіх її рівнях (початкова, базова середня, профільна середня освіта) за кількістю навчальних годин поступається показникам 
європейських країн. Тривалість навчального року в Україні ближче до найменших показників кількості навчальних днів серед європейських країн. На всіх рівнях повної загальної середньої освіти спостерігається чітка тенденція: у вітчизняній системі освіти нормативно визначено менше навчального часу на здобуття відповідного рівня освіти, ніж у країнах Європи, через що учні необґрунтовано перевантажені. Водночас тривалість канікул українських школярів - одна з найвищих, але без належної організації їхнього дозвілля і розвитку. У сукупності це веде до того, що для засвоєння змісту освітніх програм відповідного рівня повної загальної середньої освіти українським школярам надається менше часу, ніж їхнім одноліткам із європейських країн, хоча за вимогами і обсягом засвоюваних знань і набутих компетентностей українські програми еквівалентні $\epsilon$ ропейським, а в окремих випадках (наприклад, для початкової школи) навіть перевищують їх. Врешті це позначається на фізичному і психічному здоров'ї дітей, особливо молодших школярів, через невиправдано надмірну інтенсифікацію їхньої навчальної діяльності, що веде до перевтоми і виснаження.

\section{V. Загальні висновки}

За результатами порівняльного аналізу тривалості повної загальної середньої освіти в Україні та країнах Європи, можна зробити такі висновки.

1. Запровадження Законом України «Про освіту» (2017 р.) 12-річного терміну здобутмя повної загальної середньої освіти є виправданим кроком, оскільки відповідає основним засадам освітньої політики світового співтовариства, зокрема положенням Інчхонської Декларації «Освіта 2030» та відображає об'єктивну закономірність постійного збільшення часу навчання, що явно прослідковується в історії людства, особливо на сучасному етапі.

2. ЄС визнає стратегічну важливість освіти загалом і загальної середньої освіти зокрема в побудові відкритого демократичного суспільства і декларує загальну тенденцію європейських країн у подальшому подовженні тривалості навчання у школах як у межах обов'язкової, так і повної загальної середньої освіти. Сьогодні немає жодної європейської країни із терміном здобуття повної загальної середньої освіти менше 12 років. Прагнення України до ЄС неодмінно передбачає інтеграцію вітчизняної системи освіти в Європейський освітній простір, що вимагає приведення українського законодавства до норм європейської освітньої політики, зокрема і в питаннях три- валості здобуття освіти. Адже 12-річний термін здобуття повної загальної середньої освіти відповідає нижній межі її тривалості в європейських країнах.

3. Порівняння річного навчального навантаження українських школярів із рекомендованим мінімумом навчального часу на рік у країнах Європи показує, що у вітчизняній системі загальної середньої освіти на всіх ії рівнях українська школа має менше навчального часу на здобутmя освіти, ніж у європейських країнах. Водночас канікулярний період в українській школі наближається до найвищих показників серед країн Європи. Тривалість реального навчального року завдяки різним чинникам часто буває менше нормативно визначених 175 навчальних днів. Через це виникає перевантанення учнів, що позначається на їхньому здоров'ї. Тому слід розглянути можливість реального збільшення навчального року хоча 6 до середини червня.

4. Згідно з Конституцією України (стаття 53) повна загальна середня освіта $€$ обов'язковою. Вважаємо, що дану конституційну норму варто трактувати як зобов'язання держави створювати можливості для здобуття повної загальної середньої освіти впродовж життя, що не вимагає тоді обов'язкового її набуття до 18 років. Таке тлумачення цієї норми послабить фінансове і соціальне напруження, що нині існує в суспільстві, поліпшить моральний клімат в українській школі, розвантажить профільні ліцеї від частини учнів, які не збираються на цьому етапі життєвого шляху здобувати повну загальну середню освіту, а бажають одержати професію і піти працювати. 3 часом, коли в них виникне потреба в такій освіті, вони зможуть її безоплатно здобути у формах, передбачених законодавством.

5. Вважаємо, що для більш ефективного використання ресурсів доцільно ліквідувати дисбаланс між тими, хто здобуває вищу (універсиmетську) освіту, і тими, хто має намір набути профресійний фах на відповідних рівнях освіти $i$ nimu працювати. Нині в Україні більшість випускників старшої школи (близько 80\%) зорієнтовані на вступ до закладів вищої освіти, що в принципі можна розцінювати позитивно, якби усі вони були готові до продовження навчання в університеті. У цьому питанні доцільніше досягти європейських показників, адже в Європі існує приблизний паритет між тими, хто обирає навчання в універсиmemax, і тими, хто обирає шлях набуття профресії. Тому, на нашу думку, варто вжити необхідних заходів, щоб переорієнтувати частину 
здобувачів середньої освіти на професійне навчання і фахову передвищу освіту з подальшим працевлаштуванням у різних галузях економічної діяльності.

Отже, порівняльний аналіз структури і показників тривалості загальної середньої освіти в Україні та європейських країнах засвідчив, що в Європі є стійка тенденція до зростання терміну навчання учнів у школі, подовження тривалості здобуття середньої освіти за освітніми програмами академічного чи професійного спрямування, охоплення освітою усіх дітей у віці до 18 років. Ця об'єктивна закономірність розвитку людства проголошена в Декларації «Освіта 2030», прийнятій міжнародною спільнотою на Всесвітньому освітньому форумі у 2015 р. в Інчхоні (Республіка Корея). Для успішної інтеграції української освіmu dо європейського і світового освітніх просторів Україна повинна вибудовувати свою освітню політику відповідно до світових тенденцій розвитку освіти і суспільства загалом.

\section{СПИСОК ВИКОРИСТАНИХ ДЖЕРЕЛ}

Державна служба статистики України. (2020). http:// www.ukrstat.gov.ua/

Закон України «Про дошкільну освіту». (2001, 11 липня). https://zakon.rada.gov.ua/laws/show/2628-14

Закон України «Про освіту». (2017, 5 вересня). https:// zakon.rada.gov.ua/laws/show/2145-19

Закон України "Про повну загальну середню освіту». (2020, 16 січня). https://zakon.rada.gov.ua/laws/ show/463-20

Конституція України. (1996, 28 червня). https:// zakon.rada.gov.ua/laws/show/254к/96-вр

Угода про асоціацію між Україною, з однієї сторони, та Європейським Союзом, Європейським співтовари- ством з атомної енергії і їхніми державамичленами, з іншої сторони. (2014, 27 червня). https:// zakon.rada.gov.ua/laws/show/984_011

Council of the European Union. (2009). Council conclusions of 12 May 2009 on a strategic framework for European cooperation in education and training (ET 2020). https://www.cedefop.europa.eu/files/ education_benchmarks_2020.pdf

Education, Audiovisual and Culture Executive Agency (European Commission). (2019a). Compulsory education in Europe. 2019/20. https://doi.org/10.2797/643404

Education, Audiovisual and Culture Executive Agency (European Commission). (2019b). The organisation of school time in Europe. Primary and general secondary education: 2019/20. https://doi.org/10.2797/678694

European Commission - Education and Training. (n.d.). EU support for school policy. https://ec.europa.eu/ education/policies/school/about-school-policy_en

European Commission. (2010). EUROPE 2020. A European strategy for smart, sustainable and inclusive growth : Communication from the Commission. https://cutt.ly/ vghoXuY

European Commission. (2017). School development and excellent teaching for a great start in life : Communication from the Commission to the European Parliament, the Council, the European Economic and Social Committee and the Committee of the Regions. https://eurlex.europa.eu/legal-content/EN/TXT/PDF/? uri=CELEX:52017DC0248\&from $=E N$

UNESCO Institute for Statistics. (2012). International standard classification of education. ISCED 2011. http:// uis.unesco.org/sites/default/files/documents/ international-standard-classification-of-education-isced2011-en.pdf

UNESCO, UNICEF, the World Bank, UNFPA, UNDP, UN Women, \& UNHCR. (2015). EDUCATION 2030. Incheon Declaration. Towards inclusive and equitable quality education and lifelong learning for all. http:// www.unesco.org/new/fileadmin/MULTIMEDIA/HO/ED/ ED_new/pdf/FFA-ENG-270ct15.pdf

\section{GENERAL SECONDARY EDUCATION OF UKRAINE IN THE CONTEXT OF EDUCATION IN THE EUROPEAN COUNTRIES: DURATION AND STRUCTURE Scientific and analytical report}

Vasyl Kremen

DSc in Philosophy, Professor, Full Member (Academician) of NAS of Ukraine and NAES of Ukraine, President, National Academy of Educational Sciences of Ukraine, Kyiv, Ukraine

Oleksandr Liashenko

DSc in Pedagogy, Professor, Full Member (Academician) of NAES of Ukraine, Academician Secretary of the Division of General Secondary Education, National Academy of Educational Sciences of Ukraine, Kyiv, Ukraine Olena Lokshyna

DSc in Pedagogy, Professor, Corresponding Member of NAES of Ukraine, Head of the Department of Comparative Education, Institute of Pedagogy of the National Academy of Educational Sciences of Ukraine, Kyiv, Ukraine

Abstract. The report contains a comparative analysis of the structure of the national system of general secondary education in Ukraine with the education systems of thirty eight countries of the European Union Erasmus+ Program (27 EU Member States, as well as Albania, Bosnia and Herzegovina, United Kingdom, Iceland, Liechtenstein, Norway, Northern Macedonia, Serbia, Turkey, Montenegro, Switzerland). In the report the duration of education and the structure of an academic year in Ukraine and in the European countries are analyzed; conclusions are made on the compatibility of the school time and holidays length in the Ukrainian general secondary education institutions with the European ones. Based on the main trends in the development of education in the European education area, the proposals have been formulated to improve the organization of the instruction process in the Ukrainian schools in compliance with the transformations currently taking place in general secondary education in Ukraine.

Keywords: complete general secondary education; education systems of the European countries; a system of general secondary education of Ukraine; duration of education; structure of an academic year; reform of general secondary education of Ukraine.

Дата публікації: 16 жовтня 2020 р. 